\title{
Concentration of Elements in Marine Zooplankton from Coastal Waters of Boso Peninsula, Japan
}

\author{
Keiyu Marumo, ${ }^{* 1}$ Toshiaki Ishii, ${ }^{* 2}$ Yuusuke Ishikawa, ${ }^{* 1}$ \\ and Taishi Ueda $* 1$ \\ ${ }^{* 1}$ Central Laboratory, Marine Ecology Research Institute, Iwawada, Onjuku, Isumi, \\ Chiba 299-5105, Japan \\ ${ }^{*}$ Nakaminato Laboratory for Radioecology, National Institute of Radiological Sciences, \\ Isozaki, Hitachinaka, Ibaraki 311-1202, Japan
}

(Received April 4, 1997)

\begin{abstract}
Concentrations were determined for 14 elements in zooplankters, which were collected along the Pacific coast of central Japan (Boso Peninsula) from October 1991 to August 1992. Analyses were conducted by inductively coupled plasma atomic emission spectrometry and inductively coupled plasma mass spectrometry on 5 separate species of Copepoda, 2 cladoceran species and other taxonomic groups including fish eggs. Less variable concentrations were noted for most elements $(e . g . \mathrm{Ca}, \mathrm{P}$ and $\mathrm{Sr}$ ) among different species or groups, except for cladocerans and fish eggs which had higher concentrations of some major elements $(\mathrm{K}, \mathrm{Mg}$ and $\mathrm{Na}$ ). Negative correlations were found between the concentration factors determined and oceanic residence time of elements.
\end{abstract}

Key words: elemental concentration, concentration factor, copepoda, cladocera, fish egg

Marine zooplankton, as secondary producers in the marine food chain, play a key role in cycling of elements in the aquatic ecosystem." Since they constitute major diets for fishes and organisms of higher trophic levels, it is important to have information on their element compositions in order to understand the accumulation of specific elements in these planktivorous animals.

Some reports have been published on element compositions of mixed zooplankton, ${ }^{2-5)}$ but works on single zooplankton species are scarce ${ }^{6}$ due to the difficulty of obtaining samples of a single species in sufficient amounts to be analyzed.

The present study analyzed 14 elements in some separate zooplankton species and taxonomic groups, collected in neritic waters of the Pacific coast of central Japan.

\section{Materials and Methods}

Zooplankton samples were collected in waters $2 \mathrm{~km}$ off Onjuku Town, Chiba Prefecture $\left(35^{\circ} 10^{\prime} \mathrm{N}, 140^{\circ} 20^{\prime} \mathrm{E}\right)$, on the Pacific coast of Boso Peninsula, on October 3 and December 24, 1991 and April 2, June 2 and August 19, 1992. A collecting net, $60 \mathrm{~cm}$ in diameter, $200 \mathrm{~cm}$ in length and with filtering gauze of $0.328 \mathrm{~mm}$ mesh size, was towed horizontally near the sea surface. Catches were fixed with a neutral $10 \%$ formalin seawater on board to prevent the outflows of elements when frozen samples were sorted. Individuals of selected zooplankton species or taxonomic groups which were abundant enough for subsequent chemical analyses were separated by observation with binocular microscope. Sorting procedure was completed within 24 hours after collection. The sorted samples were weighed after drying at $70^{\circ} \mathrm{C}$ in an oven.

Each sample was digested with $10 \mathrm{~m} l$ of mixed acid (conc. $\mathrm{HNO}_{3}$ and $\mathrm{HClO}_{4}$ ) on a hot plate $\left(\mathrm{ca} .150^{\circ} \mathrm{C}\right.$ ). Then $0.5 \mathrm{~N} \mathrm{HNO}_{3}$ solution was added to the dried digests to get a volume of $20 \mathrm{ml}$. Concentrations of 14 elements were measured using a Shimadzu ICPQ-1012W inductively coupled plasma atomic emission spectrometer and VG Elemental Plasma Quad PQ-II inductively coupled plasma mass spectrometer. $\mathrm{Al}, \mathrm{Ca}, \mathrm{Cu}, \mathrm{Fe}, \mathrm{K}, \mathrm{Mg}, \mathrm{Mn}, \mathrm{Na}, \mathrm{P}, \mathrm{Sr}$ and $\mathrm{Zn}$ were analyzed by inductively coupled plasma atomic emission spectrometry (ICP-AES). Ba, Co and Cs were determined by ICP-MS, because detection limits of ICP-MS for most elements are higher than those of ICP-AES ${ }^{7}$. Prior to the application of ICP-AES and ICP-MS to the plankton samples, the accuracy of both techniques was examined using two standard reference materials (NBSSRM-1566 Oyster tissue and NIES-CRM-6 Mussel). Multielements analyses by both techniques with yttrium internal standard were carried out using the same standard solutions (SPEX XSTC-13).

At the time of zooplankton collection, oceanographic data such as surface water temperature, salinity, nutrient (phosphate- $\mathrm{P}$, nitrite- $\mathrm{N}$ and nitrate- $\mathrm{N}$ ) concentrations and chlorophyll-a concentration were also determined. Nutrient concentrations were measured on seawater samples filtered through GFC filters according to Parsons et $a l .{ }^{8)}$ Chlorophyll-a concentration was determined with a luminometer after filtration through GFC filters, thermal treatment at $450^{\circ} \mathrm{C}$ and extraction with dimethylformaldehyde. ${ }^{9}$ Vertical tows of the zooplankton net were carried out from a depth of $3 \mathrm{~m}$ to the surface in order to elucidate the general zooplankton composition at the collection spot. 


\section{Results and Discussion}

\section{Environmental Conditions in Survey Area}

Surface temperature and salinities were $14.0-24.1^{\circ} \mathrm{C}$ and 31.94-34.74, respectively. Nutrient concentrations were $0.06-0.52 \mu \mathrm{mol} / l\left(\mathrm{PO}_{4}-\mathrm{P}\right), 0.20-0.56 \mu \mathrm{mol} / l\left(\mathrm{NO}_{2}-\right.$ $\mathrm{N})$ and $2.10-7.88 \mu \mathrm{mol} / l\left(\mathrm{NO}_{3}-\mathrm{N}\right)$. Chlorophyll-a concentrations were $1.98-6.98 \mu \mathrm{g} / \mathrm{l}$. Wet-weights of net samples ranged from $12-59 \mathrm{mg} / \mathrm{m}^{3}$, and individual numbers of zooplankton ranged from 18-4277 individuals $/ \mathrm{m}^{3}$. Dominant species (percentage occurrence in number) were Paracalanus parvus $(61 \%)$ and Oikopleuridae $(19 \%)$ on December 24, 1991; Paracalanus parvus (30\%), Podon leuckarti (29\%), and Acartia omorii (22\%) on April 2, 1992; and Acartia omorii (94\%) on June 2, 1992 . No dominant species were observed on October 3, 1991 and August 19, 1992 because of the small number of individuals collected.

\section{Elemental Concentrations in Zooplankton Taxonomic Groups}

As shown in Table 1, the concentrations of elements measured by ICP-AES and ICP-MS are in good agreement with the certified values of the reference materials except for iron by ICP-MS. The somewhat high concentration of iron (mass number $=57$ ) measured by ICP-MS must result from the interference of molecular ions such as ${ }^{40} \mathrm{Ar}^{16} \mathrm{O}^{1} \mathrm{H}^{+},{ }^{40} \mathrm{Ca}^{16} \mathrm{O}^{1} \mathrm{H}^{+}$and ${ }^{41} \mathrm{~K}^{16} \mathrm{O}^{+}$. Therefore, we considered that the determination of iron by ICP-MS was not practical since large amounts of matrix elements such as $\mathrm{Ca}, \mathrm{K}, \mathrm{Mg}, \mathrm{Na}$ and $\mathrm{P}$ are contained in marine organisms. From the data mentioned above, we concluded that the application of ICP-AES to $\mathrm{Al}, \mathrm{Ca}, \mathrm{Cu}, \mathrm{Fe}, \mathrm{K}, \mathrm{Mg}, \mathrm{Mn}, \mathrm{Na}$, $\mathrm{P}, \mathrm{Sr}$ and $\mathrm{Zn}$, and of ICP-MS to $\mathrm{Ba}, \mathrm{Co}$ and $\mathrm{Cs}$ is reasonable for the determination of elements in the marine organisms, including plankton, studied in this work.

As we used formalin-fixed zooplankton samples, effects of the formalin preservation on subsequent results of analyses had to be experimentally tested. Euphausiid Euphausia pacifica obtained from a local fishermen's cooperative was fixed with a neutral $10 \%$ formalin seawater and then
Table 2. Change of the concentrations of elements ${ }^{*}$ in Euphousia pacifica stored in a neutral $10 \%$ formalin-seawater solution

\begin{tabular}{ccccc}
\hline Element & 0 day $^{* 2}$ & 1 day & 3 days & 7 days \\
\hline $\mathrm{Ca}$ & $22800 \pm 1120$ & $21700 \pm 1200$ & $17600 \pm 1300$ & $11500 \pm 1500$ \\
$\mathrm{Cd}$ & $0.34 \pm 0.09$ & $0.36 \pm 0.10$ & $0.34 \pm 0.09$ & $0.31 \pm 0.07$ \\
$\mathrm{Cu}$ & $20.1 \pm 1.1$ & $19.2 \pm 0.8$ & $17.1 \pm 0.8$ & $18.1 \pm 0.7$ \\
$\mathrm{Fe}$ & $21.9 \pm 2.1$ & $22.5 \pm 3.1$ & $23.2 \pm 2.6$ & $24.7 \pm 2.1$ \\
$\mathrm{~K}$ & $11000 \pm 400$ & $10420 \pm 350$ & $7740 \pm 230$ & $6500 \pm 120$ \\
$\mathrm{Mg}$ & $7360 \pm 210$ & $7840 \pm 220$ & $8790 \pm 450$ & $10700 \pm 690$ \\
$\mathrm{Mn}$ & $4.21 \pm 0.41$ & $4.02 \pm 0.99$ & $3.97 \pm 0.54$ & $3.88 \pm 0.50$ \\
$\mathrm{Na}$ & $38400 \pm 2800$ & $40700 \pm 2980$ & $48100 \pm 3140$ & $53000 \pm 4300$ \\
$\mathrm{Sr}$ & $300 \pm 20$ & $285 \pm 50$ & $260 \pm 20$ & $213 \pm 30$ \\
$\mathrm{P}$ & $13200 \pm 490$ & $12400 \pm 470$ & $10900 \pm 200$ & $8910 \pm 180$ \\
$\mathrm{Zn}$ & $67.6 \pm 3.6$ & $68.6 \pm 7.7$ & $69.8 \pm 8.0$ & $72.9 \pm 3.0$ \\
\hline
\end{tabular}

$* \mathrm{Al}, \mathrm{Co}$, and $\mathrm{Cs}$ were not examined in this experiment.

*2 Non-preserved sample

analyzed by ICP-AES and ICP-MS. Daily changes of each element in formalin-fixed euphausiid Euphausia pacifica are shown in Table 2. No prominent changes were observed in the first day for each element compared to the non-preserved sample ( 0 day). However, concentrations varied for each element on and after three days. When compared with the results of analysis on the non-preserved sample, $\mathrm{Mg}$ and $\mathrm{Na}$ concentrations tended to increase with time, while those of $\mathrm{Ca}, \mathrm{K}$ and $\mathrm{P}$ decreased during formalin preservation. Concentrations of trace elements were comparatively unaffected by this fixation treatment. The sorting of formalin-fixed zooplankton samples into species and groups and their refrigeration were carried out within 24 hours after collection. Concentration changes of these elements by the formalin treatment were estimated to be within $10 \%$ from comparison with non-preserved controls. From this result, we judged that only few effects occurred from formalin-fixation, if the sorting procedure was finished within 24 hours.

The concentrations of 14 elements analyzed in 14 zooplankton species or taxonomic groups, including two categories of fish egg, are summarized in Table 3. Copepods Calanus sinicus and Paracalanus parvus occurred abundantly for all sampling occasions except on June 2

Table 1. Concentrations of elements in the marine standard reference materials measured by ICP-AES and ICP-MS

\begin{tabular}{|c|c|c|c|c|c|c|}
\hline Elements ${ }^{* 1}$ & $\begin{array}{l}\text { NBS-SRM-1566*2 } \\
\text { Oyster tissue } \\
\text { certified values } \\
(\mu \mathrm{g} / \mathrm{g} \text { dry })\end{array}$ & $\begin{array}{l}\text { Values } \\
\text { measured by } \\
\text { ICP-AES } \\
(\mu \mathrm{g} / \mathrm{g} \text { dry })\end{array}$ & $\begin{array}{l}\text { Values } \\
\text { measured by } \\
\text { ICP-MS } \\
(\mu \mathrm{g} / \mathrm{g} \text { dry })\end{array}$ & $\begin{array}{l}\text { NIES-CRM- } 6^{* 3} \\
\text { Mussel } \\
\text { certified values } \\
(\mu \mathrm{g} / \mathrm{g} \text { dry) }\end{array}$ & $\begin{array}{l}\text { Values } \\
\text { measured by } \\
\text { ICP-AES } \\
(\mu \mathrm{g} / \mathrm{g} \text { dry })\end{array}$ & $\begin{array}{l}\text { Values } \\
\text { measured by } \\
\text { ICP-MS } \\
(\mu \mathrm{g} / \mathrm{g} \text { dry })\end{array}$ \\
\hline $\mathrm{Al}$ & - & - & - & 220 & 230 & 217 \\
\hline $\mathrm{Ca}$ & 1500 & 1510 & 1520 & 1300 & 1320 & 1330 \\
\hline Co & 0.4 & $\mathrm{ND}^{*_{4}}$ & 0.39 & 0.37 & ND & 0.38 \\
\hline $\mathrm{Cu}$ & 63.0 & 66.6 & 70.1 & 4.9 & 5.0 & 5.8 \\
\hline $\mathrm{Fe}$ & 195 & 190 & 230 & 158 & 154 & 198 \\
\hline $\mathrm{Mg}$ & 1280 & 1270 & 1300 & 2100 & 2000 & 2100 \\
\hline $\mathrm{Mn}$ & 17.5 & 16.5 & 17.4 & 16.3 & 14.8 & 17.3 \\
\hline $\mathrm{Na}$ & 5100 & 5000 & NA & 10000 & $9700^{\circ}$ & NA \\
\hline $\mathbf{P}$ & 8100 & 7900 & NA & 7700 & 7500 & NA \\
\hline $\mathrm{Sr}$ & 10.36 & 10.05 & 10.29 & 17 & 17 & 17 \\
\hline $\mathrm{Zn}$ & 852 & 865 & 882 & 106 & 103 & 112 \\
\hline
\end{tabular}

* The certified value of $\mathrm{Al}$ for oyster tissue was not reported. No certified values of $\mathrm{Ba}$ and $\mathrm{Cs}$ for oyster tissue and mussel were reported.

*2 $0.853 \mathrm{~g}$ of oyster tissue sample were digested and diluted to $100 \mathrm{ml}$.

*3 $0.978 \mathrm{~g}$ of mussel sample were digested and diluted to $100 \mathrm{~m} l$.

$*_{4} \mathrm{ND}=$ not detected because of poor sensitivity of ICP-AES

*5 $\mathrm{NA}=$ not analysed because the protection of an electron multiplier of the ICP-MS apparatus. 
Table 3. Stable elements in twelve taxa zooplankters and four species of fish eggs collected from October 1991 to August 199 collected on the Pacific coast of the Boso Peninsula

\begin{tabular}{|c|c|c|c|c|c|c|c|c|c|c|c|c|c|c|}
\hline Organisms & $\mathrm{Al}$ & $\mathrm{Ba}$ & $\mathrm{Ca}$ & $\mathrm{Co}$ & Cs & $\mathrm{Cu}$ & $\mathrm{Fe}$ & $\mathbf{K}$ & $\mathrm{Mg}$ & $\mathrm{Mn}$ & $\mathrm{Na}$ & $\mathbf{P}$ & $\mathrm{Sr}$ & $\mathrm{Zn}$ \\
\hline \multicolumn{15}{|l|}{ Sagittoidea } \\
\hline \multicolumn{15}{|l|}{ Sagitta spp. } \\
\hline 91.12 .24 & 162 & 0.275 & 8350 & 0.110 & 0.0540 & 38.0 & 253 & 1690 & 4750 & 49.0 & 15600 & 17900 & 94.6 & 92.6 \\
\hline \multicolumn{15}{|l|}{ Cladocera } \\
\hline \multicolumn{15}{|c|}{ Evadne nordmanni } \\
\hline 92.4 .2 & 229 & 3.85 & 28600 & 1.29 & 0.286 & 33.3 & 500 & 11100 & 12700 & 10.9 & 52400 & 34700 & 301 & 358 \\
\hline \multicolumn{15}{|c|}{ Evadne tergestina } \\
\hline 92.6 .2 & 489 & 1.25 & 22300 & 0.433 & 0.0172 & 17.3 & 266 & 12400 & 11300 & 3.58 & 50800 & 22200 & 243 & 231 \\
\hline 8. 19 & 452 & 2.43 & 24300 & 1.21 & 0.0307 & 12.7 & 701 & 15800 & 12300 & 4.40 & 64400 & 22000 & 275 & 167 \\
\hline \multicolumn{15}{|l|}{ Copepoda } \\
\hline \multicolumn{15}{|c|}{ Calanus sinicus } \\
\hline 91.10 .3 & 204 & 0.909 & 10700 & 0.412 & 0.0740 & 116 & 533 & $\mathrm{NA}^{*_{1}}$ & 5430 & 8.39 & 11800 & 15800 & 117 & 213 \\
\hline 12. 24 & NA & $\mathrm{ND}^{* 2}$ & 13000 & ND & ND & 18.8 & 255 & 8380 & 7040 & 3.69 & 35400 & 15000 & 183 & 91.0 \\
\hline 92.4 .2 & 186 & 3.15 & 13200 & ND & ND & 10.0 & 295 & NA & 4640 & NA & 6260 & 20300 & 122 & 245 \\
\hline 8. 19 & 815 & 1.92 & 19900 & 0.315 & 0.0343 & 19.1 & 1420 & 9000 & 8830 & 7.46 & 31800 & 25700 & 206 & 202 \\
\hline \multicolumn{15}{|c|}{ Paracalanus parvus } \\
\hline 91.10 .3 & 533 & 0.190 & 17500 & 0.247 & 0.0480 & 46.1 & 734 & 9800 & 9170 & 7.91 & 37500 & 17000 & 202 & 114 \\
\hline 12. 24 & 207 & ND & 14600 & ND & ND & 6.80 & 538 & 7900 & 6950 & 5.85 & 35700 & 14500 & 184 & 75.1 \\
\hline 92.4 .2 & 571 & ND & 33000 & ND & ND & NA & 1480 & 7700 & 11300 & NA & 11700 & NA & 280 & 464 \\
\hline 8.19 & 901 & 3.09 & 18900 & 0.459 & 0.0656 & 18.0 & 1120 & NA & 7270 & 0.900 & 18300 & 22900 & 173 & 19.3 \\
\hline \multicolumn{15}{|c|}{ Eucalanus attenuatus } \\
\hline 9 L. 12.24 & 149 & 0.761 & 7480 & 0.0865 & 0.0480 & 14.1 & 241 & 4280 & 5300 & 1.16 & 24000 & 14200 & 111 & 34.8 \\
\hline \multicolumn{15}{|c|}{ Acartia omorii } \\
\hline 92.4 .2 & 169 & 1.15 & 10600 & ND & ND & NA & 415 & 5500 & 4160 & 4.67 & 11000 & 16500 & 94.8 & 287 \\
\hline 92.6 .2 & 588 & ND & 14500 & 0.321 & ND & 25.7 & 835 & 1890 & 6330 & 4.70 & 8160 & 20500 & 137 & 179 \\
\hline \multicolumn{15}{|l|}{ Temora spp. } \\
\hline 91.10 .3 & 1330 & 1.23 & 9240 & 0.534 & 0.141 & 53.7 & 1750 & NA & 4450 & 14.2 & NA & 22600 & 93.1 & 138 \\
\hline \multicolumn{15}{|c|}{ Labidocera japonica } \\
\hline 92.8 .19 & 546 & 1.64 & 16400 & 0.336 & 0.0390 & 21.5 & 813 & 5150 & 7890 & 5.24 & 28700 & 20100 & 175 & 186 \\
\hline \multicolumn{15}{|l|}{ Oncaea spp. } \\
\hline 91.12 .24 & 393 & 2.44 & 6950 & 0.177 & ND & 15.4 & 660 & 1980 & 3640 & 3.43 & 15500 & 9850 & 86.3 & 50.0 \\
\hline \multicolumn{15}{|l|}{ Decapoda } \\
\hline \multicolumn{15}{|c|}{ Brachyura zoea } \\
\hline 91.10 .3 & 588 & 0.365 & 9570 & 0.923 & 0.0660 & 101 & 838 & 922 & 5540 & 6.24 & 16400 & 37300 & 116 & 156 \\
\hline \multicolumn{15}{|c|}{ Macrura mysis } \\
\hline 92.8 .19 & 362 & 1.74 & 17800 & 0.702 & 0.0261 & 29.5 & 709 & 4920 & 8360 & 3.82 & 30200 & 31000 & 178 & 253 \\
\hline \multicolumn{15}{|l|}{ Fish egg } \\
\hline \multicolumn{15}{|c|}{ Engraulis japonicus egg } \\
\hline 92.6 .2 & 194 & ND & 3180 & ND & ND & NA & 234 & NA & 6310 & 4.68 & 20100 & 6730 & 41.1 & 231 \\
\hline \multicolumn{15}{|c|}{ Unidentified spherical egg } \\
\hline 91.12 .24 & NA & ND & 7190 & ND & ND & 34.0 & 146 & 4800 & 18100 & 3.00 & 137000 & 4580 & 116 & 56.7 \\
\hline 92.6 .2 & NA & ND & 6570 & ND & ND & 38.0 & 239 & 5250 & 18200 & 5.06 & 130000 & 7110 & 111 & 243 \\
\hline 8. 19 & 335 & 1.85 & 8740 & 0.233 & 0.0190 & 33.7 & 555 & 4330 & 20900 & 2.54 & 103000 & 12400 & 128 & 116 \\
\hline
\end{tabular}

Values are $\mu \mathrm{g} / \mathrm{g}$ on a dry weight basis.

*1 NA; not analyzed.

*2 ND; not detected.

1992. The copepod Acartia omorii was dominant among zooplankton on this date and on April 2, 1992. The cladoceran Evadne tergestina was collected in an amount sufficient for analysis on two occasions, but other species or taxonomic groups except for unidentified spherical fish eggs could be obtained only once out of 5 sampling times. When possible, analysis of a taxonomic group obtained at a certain sampling occasion was conducted in duplicate or more replicates.

Concentration ranges of the major elements in the copepod samples were: $\mathrm{Ca}, 7.0$ to $33.0 ; \mathrm{K}, 1.9$ to $9.8 ; \mathrm{Mg}, 3.6$ to $11.3 ; \mathrm{Na}, 6.3$ to 37.5 ; and $\mathrm{P}, 9.9$ to $25.7 \mathrm{mg} / \mathrm{g}$ dry wt. The decapod larvae also showed similar concentration ranges. These values were in agreement with those for Calanus plumchrus caught in the Sea of Japan in September $1984 .^{6)}$ In the cladocerans, concentrations of $\mathrm{K}(11.1$ to
$15.8 \mathrm{mg} / \mathrm{g}$ dry wt), $\mathrm{Mg}$ (11.3 to $12.7 \mathrm{mg} / \mathrm{g}$ dry wt) and $\mathrm{Na}$ (50.8 to $64.4 \mathrm{mg} / \mathrm{g}$ dry wt) were comparatively higher than in the copepods.

Besides the crustaceans, on one occasion arrow worms (Sagitta spp.) were employed for chemical analyses, and their major element concentrations were nearly within the ranges for the copepods. Planktonic elliptic eggs of the anchovy Engraulis japonicus, and unidentified spherical fish eggs were also analyzed. The $\mathrm{Mg}$ and $\mathrm{Na}$ concentrations of the spherical eggs were 18 to 21 and 103 to $137 \mathrm{mg} / \mathrm{g}$ dry $w t$, respectively. These values were considerably higher than in the crustaceans.

Concentration ranges $(\mu \mathrm{g} / \mathrm{g}$ dry $w \mathrm{t})$ of the trace elements in the copepods were: $\mathrm{Al}, 149$ to $1330 ; \mathrm{Ba}, \mathrm{N}$.D. to 3.15; Co, N.D. to 0.534; $\mathrm{Cu}, 6.8$ to 116 ; $\mathrm{Cs}$, N.D. to $0.141 ; \mathrm{Fe}, 241$ to $1750 ; \mathrm{Mn}, 0.9$ to $14.2 ; \mathrm{Sr}, 86.3$ to 280 ; 
$\mathrm{Zn}, 19.3$ to 464 . These ranges were similar to those in the cladocerans and decapod larvae. When compared with the reported concentration of $\mathrm{Fe}(33 \mu \mathrm{g} / \mathrm{g}$ dry wt) for Calanus plumchrus from the Sea of Japan, ${ }^{6}$ concentration ranges found in the present study were considerably higher (241 to $1750 \mu / \mathrm{g}$ dry wt).

The trace element concentrations of our Sagittoidea and fish egg samples were also within the ranges of those of the crustaceans.

Generally speaking, the concentrations of most elements detected in our zooplankton samples did not differ greatly among the taxonomic groups, although the marine cladocerans Evadne spp., had higher concentrations of some of the major elements $(\mathrm{K}, \mathrm{Mg}$, and $\mathrm{Na})$. However, the $\mathrm{Fe}$ concentrations of our crustacean samples were remarkably higher than those in the Sea of Japan samples reported by Masuzawa et al. ${ }^{6}$ We are not certain whether this reflects any differences in Fe concentration in the seawater or biological characteristics of the animals between the two regions.

\section{Relationship between the Concentration Factors and the Oceanic Residence time}

Marine organisms concentrate elements through seawater and foodstuffs. Elemental equilibrium is maintained between marine organisms and their environmental waters through concentration and excretion. The concentration factor is formulated for each element as follows:

$$
C F=C_{\mathrm{PL}} / C_{\mathrm{SW}}
$$

where $C F$ is the concentration factor; $C_{\mathrm{PL}}$ is elemental concentration in zooplankton; and $C_{\mathrm{Sw}}$ is elemental concentrations in seawater. ${ }^{10)}$ Concentration factors ranged from 0.9 (Na) to $3.1 \times 10^{7}(\mathrm{Fe})$ (Table 4). Generally, $C F$ values have been reported as being low in major elements and high in minor elements. ${ }^{1)}$ Yamamoto $^{11)}$ found a log-log linear relationship between the concentration factor of zooplankton $(C F)$ and the mean oceanic residence time
$(T)$. Regarding the relation between the concentration factor and the mean oceanic residence time, Cherry et al., ${ }^{12}$ have given the following equation:

$$
\log C F=a+b \log T
$$

Mean oceanic residence time is defined as the average time an element spends in ocean water between its introduction into the ocean and its incorporation into the sediments, ${ }^{12}$ ) and is defined as follows:

$$
T=A /(\mathrm{d} A / \mathrm{d} T)
$$

where $A$ is the total amount of the element in seawater; $\mathrm{d} A / \mathrm{d} t$ is the inflow element amount to the ocean or removal amount from ocean to sediment. Masuzawa et $a l .{ }^{6)}$ gave the following equation:

$$
\tau_{\mathrm{R}}=\left(C_{\mathrm{SW}} \cdot V_{\mathrm{Sw}}\right) /\left(C_{\mathrm{RW}} \cdot F_{\mathrm{RW}}\right)
$$

where $C_{\mathrm{SW}}$ is the element content of seawater; $C_{\mathrm{RW}}$ is the mean element content of riverwater; ${ }^{13)} V_{\mathrm{SW}}$ is the total volume of seawater; ${ }^{14)}$ and $F_{\mathrm{RW}}$ is river discharge to the ocean. ${ }^{15)}$ A negative correlation on the relationship between $\log C F-\log T$ has been reported for some marine organisms such as sea algae, ${ }^{16-18)}$ phytoplankton ${ }^{17}$ and zooplankton. ${ }^{6,11)}$ The same negative correlation was seen in this study (Fig. 1). The values of $a$ and $b$ were 7.38 to 8.87 and -0.75 to -1.00 , respectively (Table 5). Generally, $a$ is 6 to 9 , and $b$ is nearly-1. ${ }^{19}$ )

In the copepods Calanus sinicus and Paracalanus par$v u s$, some elements were determined three or more different times during the year. Generally, concentrations of major elements analyzed were found to be less variable with sampling occasions. Among trace elements, some elements, such as $\mathrm{Ba}, \mathrm{Cu}, \mathrm{Zn}$, seemed to change concentrations with sampling occasions.

In marine organisms with longer life spans, seasonal variations in element concentration have been investigated

\begin{tabular}{|c|c|c|c|c|c|c|c|c|c|c|c|c|c|c|}
\hline Organisms & $\mathrm{Al}$ & $\mathrm{Ba}$ & $\mathrm{Ca}$ & Co & $\mathrm{Cs}$ & $\mathrm{Cu}$ & $\mathrm{Fe}$ & K & $\mathrm{Mg}$ & $\mathrm{Mn}$ & $\mathrm{Na}$ & $\mathbf{P}$ & $\mathrm{Sr}$ & $\mathrm{Zn}$ \\
\hline \multicolumn{15}{|l|}{ Sagittoidea } \\
\hline Sagitta spp. & $3.0 \times 10^{5}$ & 19.6 & 20.4 & $9.2 \times 10^{4}$ & $1.9 \times 10^{2}$ & $1.5 \times 10^{5}$ & $4.5 \times 10^{6}$ & 4.2 & 3.7 & $1.8 \times 10^{6}$ & 1.4 & $2.5 \times 10^{5}$ & 12.0 & $2.3 \times 10^{5}$ \\
\hline \multicolumn{15}{|l|}{ Cladocera } \\
\hline Evadne nordmanni & $4.2 \times 10^{5}$ & $2.8 \times 10^{2}$ & 69.8 & $1.1 \times 10^{6}$ & $9.9 \times 10^{2}$ & $1.3 \times 10^{5}$ & $8.9 \times 10^{6}$ & 27.8 & 9.9 & $3.9 \times 10^{5}$ & 4.9 & $4.9 \times 10^{5}$ & 38.1 & $9.2 \times 10^{5}$ \\
\hline Evadne tergestina & $8.7 \times 10^{5}$ & $1.3 \times 10^{2}$ & 56.8 & $6.9 \times 10^{5}$ & 82.8 & $5.8 \times 10^{4}$ & $8.6 \times 10^{6}$ & 35.3 & 9.2 & $1.4 \times 10^{5}$ & 5.3 & $3.1 \times 10^{5}$ & 32.8 & $5.1 \times 10^{5}$ \\
\hline \multicolumn{15}{|l|}{ Copepoda } \\
\hline Calanus sinicus & $7.4 \times 10^{5}$ & $1.4 \times 10^{2}$ & 34.6 & $3.0 \times 10^{5}$ & $1.9 \times 10^{2}$ & $1.6 \times 10^{5}$ & $1.1 \times 10^{7}$ & 21.7 & 5.1 & $2.3 \times 10^{5}$ & 2.0 & $2.7 \times 10^{5}$ & 19.9 & $4.8 \times 10^{5}$ \\
\hline Paracalanus parvus & $1.0 \times 10^{6}$ & $1.2 \times 10^{2}$ & 51.2 & $2.9 \times 10^{5}$ & $2.0 \times 10^{2}$ & $9.1 \times 10^{4}$ & $1.7 \times 10^{7}$ & 21.2 & 6.8 & $1.7 \times 10^{5}$ & 2.4 & $2.5 \times 10^{5}$ & 26.6 & $4.3 \times 10^{5}$ \\
\hline Eucalanus attenuatus & $2.8 \times 10^{5}$ & 54.4 & 18.2 & $7.2 \times 10^{4}$ & $1.7 \times 10^{2}$ & $5.4 \times 10^{4}$ & $4.3 \times 10^{6}$ & 10.7 & 4.1 & $4.1 \times 10^{4}$ & 2.2 & $2.0 \times 10^{5}$ & 14.1 & $8.9 \times 10^{4}$ \\
\hline Acartia omorii & $7.0 \times 10^{5}$ & 82.1 & 30.7 & $2.7 \times 10^{5}$ & - & $9.9 \times 10^{4}$ & $1.1 \times 10^{7}$ & 9.3 & 4.1 & $1.7 \times 10^{5}$ & 0.9 & $2.6 \times 10^{5}$ & 14.7 & $6.0 \times 10^{5}$ \\
\hline Temora spp. & $2.5 \times 10^{6}$ & 87.9 & 22.5 & $4.5 \times 10^{5}$ & $4.9 \times 10^{2}$ & $2.1 \times 10^{5}$ & $3.1 \times 10^{7}$ & - & 3.5 & $5.1 \times 10^{5}$ & - & $3.2 \times 10^{5}$ & 11.8 & $3.5 \times 10^{5}$ \\
\hline Labidocera japonica & $1.0 \times 10^{6}$ & $1.2 \times 10^{2}$ & 40.0 & $2.8 \times 10^{5}$ & $1.3 \times 10^{2}$ & $8.3 \times 10^{4}$ & $1.5 \times 10^{7}$ & 12.9 & 6.2 & $1.9 \times 10^{5}$ & 2.7 & $2.8 \times 10^{5}$ & 22.2 & $4.8 \times 10^{5}$ \\
\hline Oncaea spp. & $7.3 \times 10^{5}$ & $1.7 \times 10^{2}$ & 17.0 & $1.5 \times 10^{5}$ & - & $5.9 \times 10^{4}$ & $1.2 \times 10^{7}$ & 5.0 & 2.8 & $1.2 \times 10^{5}$ & 1.4 & $1.4 \times 10^{5}$ & 10.9 & $1.3 \times 10^{5}$ \\
\hline \multicolumn{15}{|l|}{ Decapoda } \\
\hline Brachyura zoea & $1.1 \times 10^{6}$ & 26.1 & 23.3 & $7.7 \times 10^{5}$ & $2.3 \times 10^{2}$ & $3.9 \times 10^{5}$ & $1.5 \times 10^{7}$ & 2.3 & 4.3 & $2.2 \times 10^{5}$ & 1.5 & $5.3 \times 10^{5}$ & 14.7 & $4.0 \times 10^{5}$ \\
\hline Macrura mysis & $6.7 \times 10^{5}$ & $1.2 \times 10^{2}$ & 43.4 & $5.9 \times 10^{5}$ & 90.0 & $1.1 \times 10^{5}$ & $1.3 \times 10^{7}$ & 12.3 & 6.5 & $1.4 \times 10^{5}$ & 2.8 & $4.4 \times 10^{5}$ & 22.5 & $6.5 \times 10^{5}$ \\
\hline \multicolumn{15}{|l|}{ Fish egg } \\
\hline $\begin{array}{l}\text { Engraulis } \\
\quad \text { japonicus egg }\end{array}$ & $3.6 \times 10^{5}$ & - & 7.8 & - & - & - & $4.2 \times 10^{6}$ & - & 4.9 & $1.7 \times 10^{5}$ & 1.9 & $9.5 \times 10^{4}$ & 5.2 & $5.9 \times 10^{5}$ \\
\hline $\begin{array}{l}\text { Unidentified } \\
\text { spherical egg }\end{array}$ & $6.2 \times 10^{5}$ & $1.3 \times 10^{2}$ & 18.3 & $1.7 \times 10^{5}$ & 65.5 & $1.3 \times 10^{5}$ & $5.6 \times 10^{6}$ & 12.0 & 14.9 & $1.3 \times 10^{s}$ & 11.4 & $1.1 \times 10^{5}$ & 14.9 & $3.6 \times 10^{5}$ \\
\hline
\end{tabular}
and related to growth, reproduction or other life cycle stages. ${ }^{20-25)}$ Copepods in temperate waters, however, are

Table 4. Concentration factors of zooplankton and fish egg 

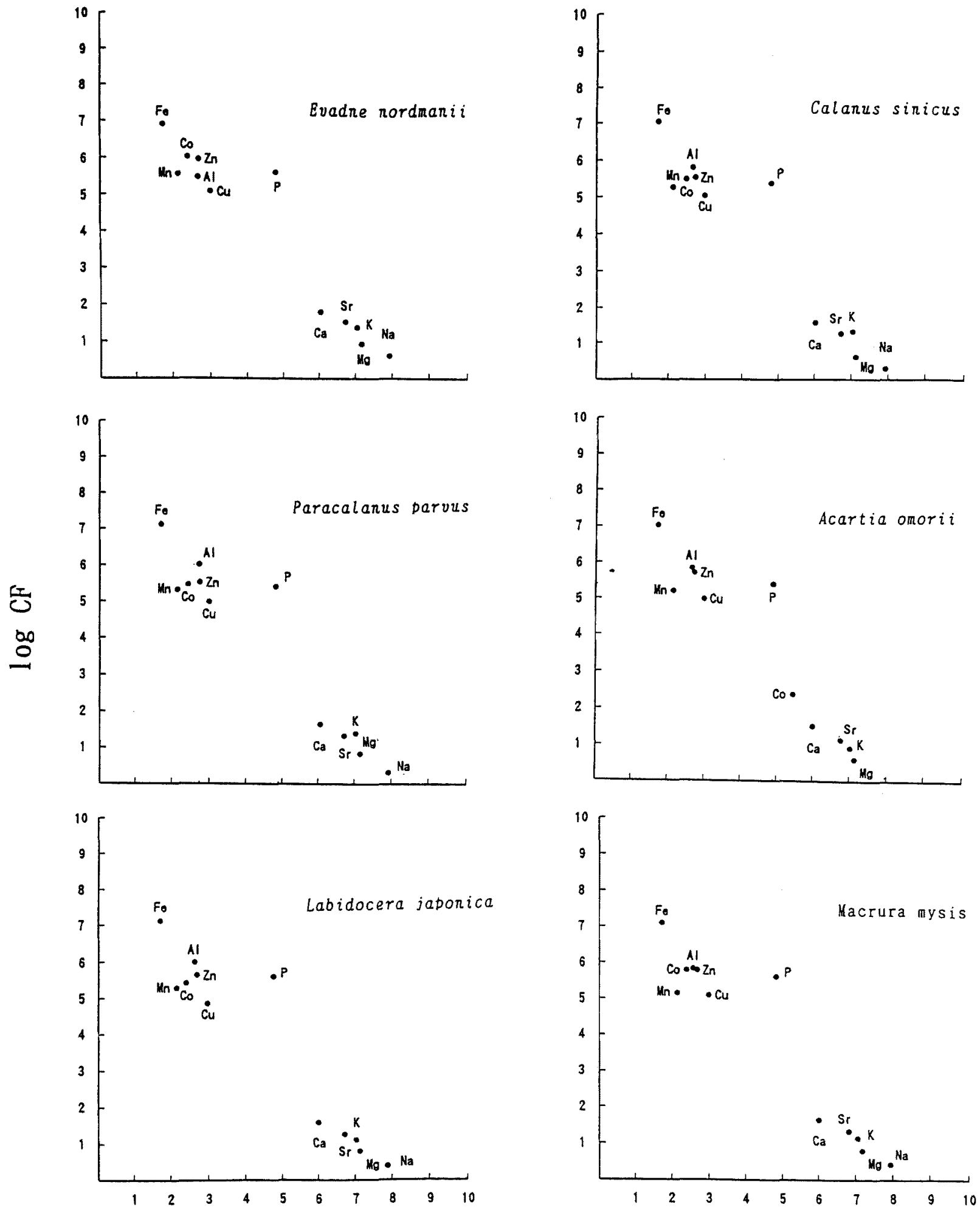

$\log \mathrm{T}$

Fig. 1. Plots of $\log C F-\log T$ for four copepods, Calanus sinicus, Paracalanus parvis, Acartia omorii, and Labidocera japonica, one cladoceran, Evadne nordmanni, and one decapod Macrura mysis.

$T$ values are calculated from the river input data. 
Table 5. Coeffients of $a$ and $b$ for zooplankton and fish egg in the following formula

\begin{tabular}{lcc}
\hline \multicolumn{1}{c}{ Plankton species } & $a$ & $b$ \\
\hline Sagitta spp. & 8.67 & -0.99 \\
Evadne nordmanni & 7.88 & -0.75 \\
Evadne tergestina & 8.15 & -0.84 \\
Calanus sinicus & 8.40 & -0.91 \\
Paracalanus parvus & 8.39 & -0.90 \\
Acartia omorii & 7.98 & -0.82 \\
Labidocera japonica & 8.42 & -0.91 \\
Brachyura zoea & 8.87 & -1.00 \\
Macrura mysis & 8.33 & -0.89 \\
Engraulis japonica egg & 7.38 & -0.79 \\
\hline
\end{tabular}

$\log C F=a+b \log T$.

shorter-lived and repeat several generations within a year. Little has been reported as to whether the concentrations and compositions of elements vary depending on different generations, populations or stages of copepods. Accordingly, we are planning to clarify these subjects. By using ICP-AES and ICP-MS which have some analytical advantages such as satisfactory accuracy, high sensitivity and wide dynamic range, it would be possible to investigate seasonal and stage variations in future.

Acknowledgments We thank Drs. R. Hirano and I. Hanyuu, Profes sors Emeritus, at the University of Tokyo, who checked our manuscript and provided constructive comments. We also thank Mr. R. Isono, who offered the data on nutrients and chlorophyll-a.

\section{References}

1) S. W. Fowler: Trace elements in zooplankton particulate products. Nature, 269, 51-55 (1977).

2) Z. A. Vinogradova and V. V. Kovalevskij: Elemental composition of the Black Sea plankton. Doklady Acad. Sci. USSR, Earth Sci. Sec., 147, 217-219 (1962).

3) J. H. Martin and G. A. Knauer: The elemental composition of plankton. Geochim. Cosmochim. Acta, 37, 1639-1653 (1973)

4) A. Bohn and R. O. McElroy: Trace metals (As, Cd, Cu, Fe and $\mathrm{Zn}$ ) in Arctic cod Boreogadus saida and selected zooplankton from Strathcona Sound, Northern Baffin Island. J. Fish. Res. Bd. Cana$d a$, 33, 2836-2840 (1976).

5) P. S. Tijoe, J. J. M. de Goeij, and M. de Bruin: Determination of trace elements in dried sea plant homogenate (SP-M-1) and in dried copepod homogenate (MA-A-1) by means of neutron activation analysis, Interuniv. Reactor Inst. Rept., 133-77-05, Delft, Netherland 1977, p. 14.

6) T. Masuzawa, M. Koyama, and M. Terazaki: A regularity in trace element contents of marine zooplankton species. Mar Biol., 97,
587-591 (1988).

7) T. Ishii, M. Nakahara, M. Matsuba, and M. Ishikawa: Determination of ${ }^{238} \mathrm{U}$ in marine organisms by inductively coupled plasm mass spectrometry. Nippon Suisan Gakkaishi, 57, 779-787, (1991).

8) T. R. Parsons, Y. Maita and C. Lalli: A manual of chemical and biological methods for seawater analysis. Pergamon Press. London, 1984, p. 173.

9) R. Suzuki and T. Ishimaru: An improved method for the determination of phytoplankton chlorophyll using $\mathrm{N}, \mathrm{N}$-Dimethylformamide. J. Oceanogr. Soc. Japan, 46, 190-194 (1990).

10) K. W. Bruland: Trace elements in the seawater, in Chemical Oceanography (ed. by J. P. Riley and R. Chester), Academic Press, London, 1983.

11) T. Yamamoto: The relations between concentration factor in seaweeds and residence time of some elements in sea water. Rec. Oceanogr. Works Japan. 11, 65-71 (1972).

12) R. D. Cherry, J. J. W. Higgo, and S. W. Fowler: Zooplankton fecal pellets and element residence times in the oceans. Nature, 274, 246-248 (1978).

13) J. M. Martin and M. Meybec: Elemental mass-balance of materia carried by major world river. Mar. Chem., 7, 173-206 (1979).

14) H. W. Menard and S. M. Smith: Hypsometry of ocean basin provinces. J, geophys. Res., 71, 4305-4325 (1966).

15) A. Baumgartner and E. Reitel: The world water balance. Elesevier, Amsterdam, 1975.

16) T. Yamamoto, Y. Otsuka, M. Okazaki, and K. Okamoto: The dis. tribution of chemical elements in algae., in "Marine Algae in Pharmaceutical Science" (ed. by H.A. Hoppe, T. Levning, and Y. Tanaka), Walter de Gruyter, Berlin, 1979, pp. 567-607.

17) T. Yamamoto, Y. Otsuka, M. Okazaki, and K. Okamoto: A method of data analysis on the distribution of chemical elements in the biosphere, in "Techniques in Environmental Chemistry" (ed. by J. Albaiges), Pergamon Press, London, 1980, pp. 401-408.

18) T. Kawashima, T. Yamamoto, and Y. Koda: Neutron activation analysis of Japanese seaweeds. Chem. Sco. Jap., 3, 368-379 (1983).

19) D. H. Spaargaren and H. J. Ceccardi: Some relations between the elementary chemical composition of marine organisms and that of sea water. Oceanol. Acta, 7, 63-76 (1984).

20) G. W. Bryan: The occurrence and seasonal variation of trace metals in the scallops Pecten maximus and Chlamys opercularis. J. mar. biol. Ass. U.K., 53, 145-166 (1973).

21) R. J. Pentreath: The accumulation from water of ${ }^{65} \mathrm{Zn},{ }^{54} \mathrm{Mn},{ }^{88} \mathrm{Co}$ and ${ }^{59} \mathrm{Fe}$ by the mussel, Mytilus edulis. J. Mar. Biol. Ass. U.K., 53, 127-143 (1973).

22) S. W. Fowler and B. Oregioni: Trace metals in mussels from the $\mathrm{N}$. W. Mediterranean. Mar. Poll. Bull., 7, 26-29 (1976).

23) C. R. Boyden: Effect of size upon metal content of shellfish. J. Mar. Biol. Ass. U.K., 57, 675-714 (1977),

24) T. Ishii, Y. Suzuki, and T. Koyanagi: Determination of trace elements in marine organisms-l. Factors for variation of concentration of trace element. Nippon Suisan Gakkaishi, 44, 155-162 (1978).

25) T. Ueda, T. Ishii, M. Nakahara, R. Nakamura, Y. Suzuki, and C. Shimizu: Elements in gonad of the sea urchin Strongylocentrotus nudus. Nippon Suisan Gakkaishi, 57, 1095-1102 (1991). 